\title{
THE ROMANIAN INFANTRY TRAINING IN 1943
}

\author{
Ionel HALIP \\ "Ştefan cel Mare" University, Suceava, Romania \\ halip.ionel18@yahoo.com
}

\begin{abstract}
This article analyzed, the evolution of the Romanian army training in the year of 1943 under German influence. It presents the main issues the Romanian army had to face starting with the low employment of subunits with recruits up to the commanders and soldiers' level of training as individual fighters. The troupes, commissioned and non-commissioned officers training were accomplished in three stages having presented the results acquired during the war, the proprieties of the newly introduced weaponry, command exercises, field application or ski courses. On the other hand, this article presents the way in which the necessary weaponry was provided, the level of facilities and also the evolution of costs needed for yearly shootings. At the same time there are presented aspects regarding the mutations suffered by the Romanian military education, that had to rise up to the level of the European one; the way in which new classes of officers and non-commissioned officers are trained, the education in military high schools, the training in regular schools and also aspects regarding low-level military training.
\end{abstract}

KEYWORDS: weaponry, infantry, training, education, war

\section{Introduction}

One of the lessons learned in the First World War was the necessity of the Romanian State to develop military politics aimed at perfecting the training for the entire military personnel.

The combat training of Romanian infantry surrounding the start of the Second World War was executed under the guidelines of "The general directive for military training" with a practical character through repeated execution by every soldier for the role they were called to execute in war. At the same time in the provisions of the directives was stipulated that: "war demands from military men, now more than in the past, a mighty soul, a strong body and well-developed tactical and technical knowledge, with execution as a reflex" (Romanescu, Tudor, Cucu \& Popescu, 1985 , p. 253). After the acquirement of the technical properties and usage of infantry weapons available, the remaining time was used for practical application on the field based on a training program approved by the commander of the military unit. Likewise, during the training they insisted on the patriotic and moral training of the soldiers, because it was considered that the greatest threat wasn't tanks but the enemy troupes marching behind them (Romanescu, Tudor, Cucu \& Popescu, 1985, p. 255).

Starting 1941, in the process of the Romanian infantry training, were introduced in spite of the Romanian officer's opposition (Şuţa, 1982, p. 210) fighting principles of the German army; translated as "The German infantry regulation training" with adaptations specific to the needs of the Romanian infantry. The deficiency of the German doctrine and strategy materialized in the military failures that followed (Romanescu et al., 1985, p. 257). 
The evolution of the enemy's combat techniques and strategies, the countermeasures taken by the German and Romanian troupes as well as the new means of combat emerging on the battlefield has issued the necessity to adapt the training process.

Based on the lessons learned on the battlefield and the directives from the German High Command, the Romanian army wished to perfect: the defense against armor-plated means, the back safety against partisans and paratroopers, night combat, combat in villages, the knowledge and usage of the new combat means received from the Germans or taken from captures.

\subsection{Research Methodology}

The main focus of this article is to analyze the Romanian army's level of training in 1943, based on the assumptions that: the training done in 1943 had risen to meet the expectations of the commanding echelon, having become more efficient by involving more soldiers and superior material resources in comparison to the 1939-1940 period, and that the modifications brought to the Romanian military education had risen to the level of the European one. The research was accomplished by studying documents from the National Military Archives in Piteşti, but also studying specialty literature.

\section{The Troupes' Training}

The infantry's combat training in 1943 was accomplished according to the german principles through collaboration with german military instructors, but also owing to the Romanian officers participating in specialization courses in Germany (Romanian General Staff, 1944, p. 4) based on the lessons learned from the eastern campaign in the year 1942. The operations where the Romanian infantry participated in 1941-1942 highlighted the lack of training among commissioned and non-commissioned officers, especially the reserve military and the units. It was noticed the defective employment of small units, the poor training of the officers, the soldiers' lack of efficiency as individual fighters, but also the lack of training in the unit regarding coordination and fire usage (Romanian General Staff, 1944, p. 3).

The troupes' training in 1943's army was aimed at both recruits and reserve military, having been divided into three stages: stage one since January $1^{\text {st }}$ to April $1^{\text {st }}$ - the date of the recruits' induction (intended for training the non-commissioned officers); stage two: April $1^{\text {st }}$ to November $20^{\text {th }}$ (the end of the training year, intended for training the recruits); stage three: November $22^{\text {nd }}$ carrying through January 1944, when the training of all commissioned and non-commissioned officers were achieved before the conscription of the contingent of 1945.

At the beginning of 1943 , there were 315.853 military men in training out of which 216.000 were basarabians and bukovinans (Romanian General Staff, 1944, p. 5). The results of the training were mediocre from lack of employment of instructors, but also the fairly short period of training ( 3 days a week). In January $1^{\text {st }}$ 1943, the available officers and noncommissioned officers in the entire army was a third of what was needed (Romanian General Staff, 1944, p. 9).

An attempt was made to solve this issue by organizing and functioning for 3 months of 11 divisionary training centers, where 1900 backup officers were assembled, but they still didn't cover the army's needs (Romanian General Staff, 1944, p. 9). On the other hand, the officers and noncommissioned officers were participating in theoretical sessions (once a week) where they analyzed the acclimation of german regulations for Romanian particularities, the lessons learned during the war or the proprieties of the newly introduced weaponry. Likewise, they were exercising command training for subunits, participating 
in field application weekly, and alongside the garrison monthly.

In the second stage, there was a superior officer training about 500-600 recruits, a captain for 150-200 recruits, a non-commissioned officer for 40 recruits and 2 ranked-instructors for 10 recruits. At the same time, the employment of officer recruits and back-up noncommissioned officers beside active ones was in 1943 for the infantry in proportion of 2/3 (Romanian General Staff, 1944, p. 10). During this time demonstrative trainings were organized with students of military schools for officers and non-commissioned officers, active and reserve, also different directives and instructions had been put together such as: the Brochure "The professional training of the entire military personnel", Analytical Programs attached to the Training Directives in the Military and Instructions for Leading the Antitank Training.

In the third stage, officers and noncommissioned officers' school was implemented as well as refresher course for ski instructors (Romanian General Staff, 1944), it started paying close attention to winter time training. The ski popularity was extended to all categories of youths: pupils, kids outside of school, military high schools, regular high schools, pre-military and students. Since December 1943 to February 1944, around 8000 skiers were formed and 240 instructors. The army played an important role in their training, by offering financial resources, and also human resources, at the same time taking care of the organization, guidance and control of these classes.

The german model was adopted also in regards to organizing the shooting range, by building in 1943 a total of 5 ranges in Bucharest, Ploieşti, Brăila, Focşani and Bacău.

Although an attempt was made to supplement the openings left by the campaigns in 1941-1942, the participation of personnel for training and specializing in Germany, the raising of the budget compared to 1942, wasn't enough for reaching the target of the training. This issue could have been solved in between the two world wars by creating a supply of commissioned and non-commissioned officers and conditions for military schools in order to assure a permanent replenishment.

\subsection{The Acquisition of Weaponry}

The necessary weaponry for the training was provided both through exchanges between units, and also by using the captured weaponry, because the Romanian infantry was dealing with a precarious endowment of modern weaponry. In Figure no. 1 is shown that the biggest deficiency was that of antitank cannons, and also antiaircraft machine-guns.

At the same time an attempt was made to organize demonstrative training using captured tanks, presenting their main characteristics and ways of fighting against them (Romanian General Staff, 1944, p. 11).

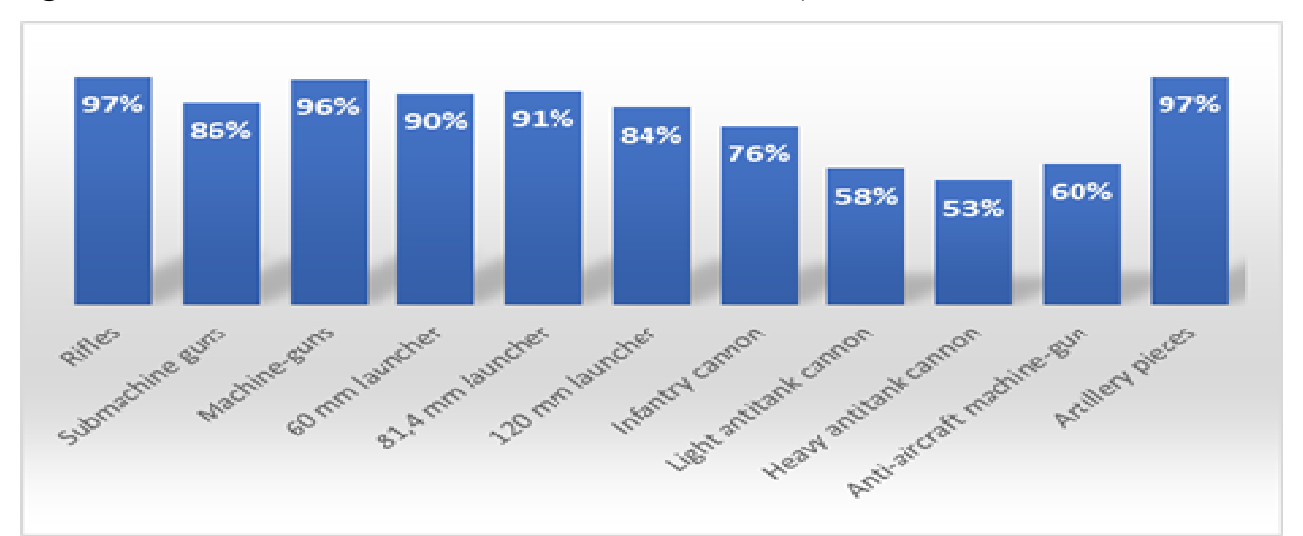

Figure no. 1: The existing percentage of weaponry in relation to what was needed (Source: Romanian General Staff, 1944, p. 40) 
As a result of acquiring antitank cannons of $55 \mathrm{~mm}$ and $75 \mathrm{~mm}$, actions were taken to prepare military men by establishing at Mihai Bravu a center of antitank training, having brought in August 20 1943 the necessary individuals towards further specialization. This center had trained in 1943 a number of 575 officers, 375 noncommissioned officers and 750 lower ranks (Romanian General Staff, 1944, p. 29).

Between the $10^{\text {th }}$ and $21^{\text {st }}$ of October there were organized in Cincu Mare region 3 practical applications using joint weapons and real shootings (scouting, defense and attack). For these demonstrations German officers have collaborated, and presented means of organizing, guiding, controlling and executing the training (Romanian General Staff, 1944, p. 12), where all the small and big units' commanders participated in. That being said, the training standard was low because of the lack of continuity among the instructors, through participating to different courses and schools held during the training period, but also from the lack of interest among the reserve officers.

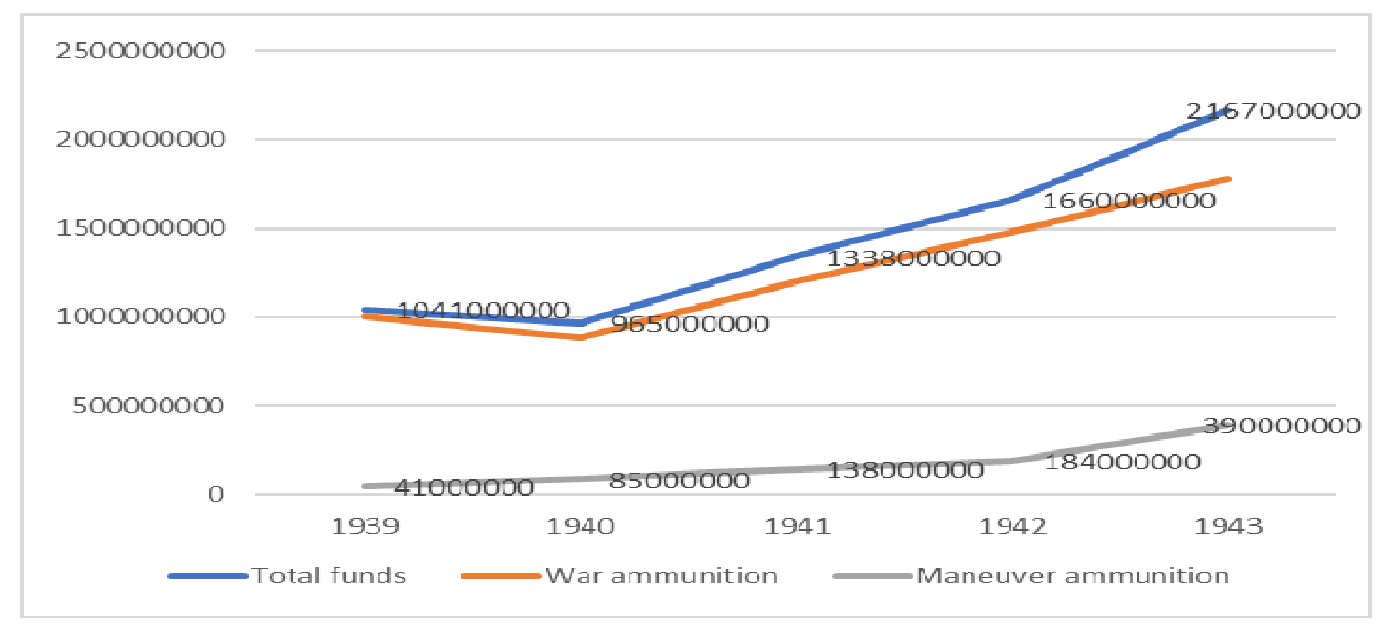

Figure no. 2: The evolution of costs for annual shootings during 1939-1943

(Source: Romanian General Staff, 1944, p. 55)

On the other hand, from the diagram above, we can observe that the evolution of costs for the annual shootings had risen constantly, doubling both the budget and ammunition spent on the 1943 shooting in comparison to the amount recorded around the beginning of World War in 1939.

\section{Romanian Military School}

In school year 1943 the following infantry schools were active: the school of active infantry officers in Bucharest; 4 schools of reserve infantry officers in Ploieşti, Bacău, Câmpulung Muscel and Arad, 4 schools of infantry non-commissioned officers in Făgăraş, Botoşani, Bucharest and Lugoj (Şuţa, 1982, p. 207), and 9 schools of non-commissioned officers. The total number of students in officer schools was of 10310 youngsters, taking the exam for the rank of second-lieutenant 1578 students belonging to the schools of active officers and 1432 from the schools of reserve officers.

The Romanian military school faced important mutations in the field of collaboration, organization, the content of the program for training and developing commissioned and non-commissioned officers. In general, it had risen to the level of the European military education. The Superior Management for Military Education operating under the General Staff was ensuring at that time the coordination of all education institutes towards attaining a homogeneous training using all weapons (Pascu et al., 1989, p. 544). 
Due to the war, there was an urge to adopt some ways to form classes of officers and non-commissioned officers by reducing the school year, at the same time new schools were established which increased their capacity (Pascu et al., 1989, p. 546). Also, they accepted young men without examination in order to become reserve officers and non-commissioned officers just by equating their previous education; also allowing high school graduates without a bachelor's degree or those who had commercial studies (Pascu et al., 1989, p. 547). Through these measures, there was an increase in the number of schools and at the same time an increase in the effectives of active and reserve officers as follows: 4086 graduates in 1944 and 4156 graduates in 1945. Regarding the non-commissioned officers in 1943, there were 3211 graduates out of active non-commissioned officers' school and 1144 from the reserve school.

The superior military education was still represented by the Higher War School which had the mission of forming staff officers capable of commanding large units on the battlefield (Pascu et al., 1989, p. 547).

At the same time, the General Staff had shown a real and constant interest in regards to forming and educating the young men, being aware of the fact that they represent the future of the country. Thereby, in parallel with the training and education inside the army, the General Staff took care of stirring the young towards the military and defending the country. More precisely, they cared for military training and educating the young, and also technical guiding (auto, aviation, conveyance) target practice and sport activities applicable in the army (Romanian General Staff, 1944, p. 35).

Mainly, the Ministry of National Culture was the one taking care of training and education in schools according to the curriculum for secondary education elaborated by the members of the fore mentioned ministry, however at the solicitation from the General Staff, the military training and education of military high school students was intensified through:

- Modifying the curriculum so as to introduce the obligation of getting familiar with not only the riffle but also the entire infantry weapons available.

- The functioning of 4 summer camps (448 students) for improving training (including auto, conveyance) and 137 other students attended nonpower aircraft schools (Romanian General Staff, 1944, p. 33).

The results were satisfying, the military high schools continued to be the best organized schools of secondary education all throughout the country.

\subsection{Military Training in Regular Schools}

In regular schools military training and education were introduced at the order of marshal Antonescu beginning with school year 1943-1944.

According to the agreement between the General Staff and the Ministry of National Culture, a class of military instructors was put together which functioned uninterrupted over a period of 40 days (July $20^{\text {th }}-$ August $30^{\text {th }}$ ) at Breaza, where 21 active officers, 42 reserve officers and 183 students from grades 7-8 had participated. This class aimed for getting to know and practice the military training being taught at the time, and also the unification of the methods of training and educating (Romanian General Staff, 1944, p. 34).

In regards to the training program and military education practiced in regular schools, it is necessary to mention that they did not differ much from the ones practiced in military high schools. The implementation of the programme aimed for a more complex and balanced education of the students. Therefore, along with the knowledge accumulated for vocational training, the student had to also have certain skills specific to a reserve officer, as well as: discipline, the 
innate order and authority of a military man, so that the military training complements the cultural and professional one.

\subsection{Premilitary Training}

The training and education of premilitary men was achieved according to law and special preliminary directives under the direct rule of Undersecretary of State for Extracurricular Education, and subsequently under the rule of Undersecretary of State for Schools.

In spite of the difficulties met from lack of personnel and weaponry, the head of premilitary training managed to keep awake the conscience of around 40000 premilitary men who have contributed to community labor and war work with a significant number of premilitary men over a considerable period of time, attaching importance to the duty of forming specialists according to the army's needs, thus 1834 drivers, 950 tractor drivers, 150 motorcyclists, 757 telegraph operators, 467 radiotelegraph operators, 1627 phone operators, 40 Huges mechanics and 737 skiers were formed (Romanian General Staff, 1944, p. 35).

\section{Conclusions}

Through this article, the two hypotheses that started the research have been confirmed.

The training in 1943 rose up to the expectations of the commanding echelon due to the fact that the entire training process was done in collaboration with German instructors, attempting to solve the problems from 1941-1942. The strengths of the 1943's training were: securing training for all categories of personnel during the three stages of training, the establishing of 12 centers for training, one being antitank, and also the making of those 5 shooting ranges. On the other hand, a weakness in the 1943's training was the insufficient acquirement of modern weaponry such as antitank cannons or antiaircraft machineguns. Nevertheless, the evolution of costs for ammunition for the other categories of weapons had risen constantly, doubling the amount compared to the year 1939.

The Romanian military education rose to the level of the European one for in 1943, in Romania, there were up and running a number of 18 schools for active officers, reserve officers or non-commissioned officers, where a homogenous training was done for all weapons. The problem raised by the lack of recruits, commissioned and non-commissioned officers was solved by training in a short amount of time the entire military personnel.

In conclusion, along with all the losses suffered by the Romanian infantry in order to secure training for the effectives, the efforts of organizing and training the troupes in order to maintain the Romanian army at a suitable level were not in vain, reaping the benefits during the tough encounters with Hitler's troupes beginning on the $23^{\text {rd }}$ of August 1944.

\section{REFERENCES}

Pascu, Ş. et al. (1988). Istoria militară a poporului român. Vol. VI, Evoluţia sistemului militar naţional în anii 1919-1944. Bucureşti: Editura Militară.

Romanescu, G., Tudor, G., Cucu, M., \& Popescu, I. (1985). Istoria infanteriei române. Vol. II, București: Editura Militară.

Romanian General Staff. (1944). Darea de seamă asupra instrucţiei în armată - 1943. Inventory no. 667, Military Archives of Piteşti, Section 5.

Şuţa, I. (1982). Infanteria română de la Primul Război Mondial până în zilele noastre. Vol. II, Bucureşti: Editura Militară. 